\title{
Chemical Composition and Antimicrobial Activity of Essential Oil from Eupatorium triplinerve Vahl. Aerial Parts
}

\author{
N.SUGUMAR*, S.KARTHIKEYAN and T.GOWDHAMI. \\ Department of Botany, Annamalai university, AnnamalaiNgar, 608 002. TamilNadu, India. \\ Email: nsugumar47@gmail.com
}

\begin{abstract}
Eupatorium triplinerve Vahl belongs to the Asteraceae family, popularly known as Ayapana .It is a perennial shrub native to Amazon rainforests of South America. Its leaves are used through infusions, decoctions, baths, and tea. It is largely used in Brazilian folk medicine as sedative, febrifuge, stimulant, tonic and anti-inflammatory. The essential oil from aerial parts of Eupatorium triplinerve was analysis by gas chromatography mass spectroscopy (GC-MS). Thirty compounds representing $98.24 \%$ of the oil were identified. The major compounds were 2-tert- butyl $-1,4$ - methoxybenzene $(74.3 \%)$ and b Selinene $(8.6 \%)$. The antibacterial activity of the essential oil was evaluated against ten bacteria (including Gram positive and Gram negative) and six phytopathogenic fungi. The oil exhibited moderated antibacterial and strong antifungal activity against all the test pathogens. The highest zone inhibition was recorded against Salamella typhae $(21 \mathrm{~mm})$ followed by Shigella sonnei $(18 \mathrm{~mm})$ at a concentration of $20 \mu 1 /$ disc on the other standard Ampicillin $20 \mathrm{mg} /$ disc showed on average of $14-34 \mathrm{~mm}$ diameter of zone inhibition against the test organism. The lowest antifungal activities were recorded against Macrophomina phaseoline, and Botryodiplodia theobromae. The highest Alternaria alternate (12000ppm).Further pharmacological and toxicology studies will be required to establish the therapeutic uses of this oil.
\end{abstract}

KEYWORD: Eupatorium triplinerve, Antimicrobial activity, Essential oil, GC-MS, 2-tert- butyl-1, 4methoxybenzene.

\section{INTRODUCTION}

Eupatorium triplinerve Vahl. Commonly called Ayapana (Syn. Ayapana triplinerve and Eupatorium ayapana) is an ornamental erect perennial herb with aromatic leaves is under the family Asteraceae. Most of the people in rural and urban areas of the world were depended on the medicinal plants for the treatment of infectious diseases. The Ayurvedic and Unani systems of medicines are widely used by the people of Indian subcontinent. Among the different plant derivetives, secondary metabolites proved to be the most important group of compounds that showed wide range of antibacterial and antifungal activity (Ahmed et al.2002, Rahman et al. 
1998). Eupatorium triplinerve (Compositae) is a slender herb with narrow lanceolate leaves and large number of pedicelled flower-heads at the top of the branch, cultivated in Chittagong and Chittagong Hill Tracts. Extract of the plant is used as antiseptic, and in the treatment of various ulcers and hemorrhages (Ghani 1998). This paper reports the result of antimicrobial activity of E. triplinerve on folk usages by traditional practitioners in Tribal areas of Bangladesh. Ayapana is a rich source of naturally occuring coumarin chemicals and is used in herbal medicine as antitumor remedy. It was reported that a coumarin chemical named hernarin (7-methoxycoumarin) was toxic to cancer cells including multi drug resistant cancer cells (Canales et al., 2005; Yadava and Saini, 1980) and leukemic cells (Garg and Nigam, 1970). Garg and Nigam (1970) reported the presence of thymohydroquinone dimethylether, coumarin, borneol and bornyl acetate along with seven monoterpenoids in the leaf oil. Later,( Garg and Nakhare,1993) analyzed the flower oil of E. triplinerve and found thymohydroquinone dimethylene $(50.3 \%)$, followed by borneol $(5.81 \%)$ and isoeugenol $(4 \%)$ as the major constituent, along with other minor constituents. The essential oil of the flowers has yielded much better antimicrobial results than the plant itself. Ayapana flowers essential oil possess strong antifungal activity against 10 strains of fungi in vitro (Sharma and Singh, 1979). It also possesses antibacterial (against staph, cholera, pneumonia and shigella) as well as antiparasitic (Ascaris) and anthelminitic (Taenia) actions (Garg and Nakhare, 1993). In an early animal study, the flower essential oil injected into mice was reported to have CNS depressant, analgesic and sedative effects (as well as an in vitro antibacterial effect) (Kokate and Verma, 1971). Ghani (2003) reported the presence of coumarin, ayapanin and ayapin having pronounced haemostatic properties. There is no report on the essential oil of E. triplinerve of local origin and its antimicrobial properties. So, the aim of the present study was to investigate the chemical composition and antimicrobial activity of the essential oil of E. triplinerve aerial parts growing in Bangladesh in order to find out new natural antimicrobial agents.

\section{MATERIALS AND METHODS}

Collection of Plant material The fresh leaves of the plant Eupatorium triplinerve Vahl were collected from State Forest Research Institute Vandal, Kanchipuram District, and TamilNadu. It was identified and authenticated in P.G Department of Plant Biology \& Plant Biotechnology, Presidency College Chennai, and TamilNadu.

Extraction of essential oil: The experiment was conducted when the plants were healthy and well-grown. For extracting of essential oil aerial parts $(5 \mathrm{Kg})$ were subjected to hydro distillation using a modified Clevenger apparatus (Clevenger, 1928) for 4 hours. The oil sample was stored at freeze in air-tight containers after drying them over anhydrous sodium sulfate for GC-MS analysis.

Test organisms: The essential oil obtained from E. triplinerve aerial parts was tested for its antibacterial activity against ten pathogenic bacteria, viz., Bacillus subtilis, B. megaterium, Staphylococcus aureus, B. cereus, Escherichia coli, Pseudomonas sp., Shigella dysenteriae, S. sonnei, Salmonella typhi, and Vibrio cholerae, and six phytopathogenic fungi viz., Alternaria alternata (Fr.) Kedissler, Botryodiplodia theobromaepat., Colletotrichum corchori Ikata (Yoshida), Curvularia lunata (Wakker) Boedijin, Fusarium equiseti (Corda) Sacc. and Macrophomina phaseolina (Maubl) Ashby. 
Antibacterial activity: The in vitro antibacterial activity of the oil was determined by disc diffusion method (Bauer and Kirby, 1966). Nutrient agar medium was used for culture of bacteria. Each experiment was repeated thrice. All the results were compared with the standard antibacterial antibiotic Ampicillin $(20 \mu \mathrm{g} / \mathrm{disc})$.

Antifungal activity: The in vitro antifungal activity of the essential oil of E. triplinerve was determined by poisoned food technique (Grover and Moore, 1962). Potato dextrose agar medium was used for culture of fungi. Each experiment was repeated thrice. Linear mycelia growth of fungus was measured after 3-5 days of incubation. The percentage inhibition of radial

\section{Determination of minimum inhibitory concentration (MIC) against bacteria and minimum bacterial concentration (MBC)}

Minimum inhibitory concentration (MIC) and minimum bactericidal concentration (MBC) of the essential oil against ten test bacterial isolates were determined by micro and macro dilution broth technique (Jones et al., 1985) using Muller Hinton medium. The MIC and MBC experiments were carried out using 100-25000 ppm concentrations of the essential oil.

\section{Determination of minimum inhibitory concentration (MIC) against fungus and minimum fungicidal concentration (MFC)}

The MIC and MFC of essential oil against six test fungi were determined by micro and macro-dilution broth technique (Jones et al., 1985) using Sabouraud medium. The MIC and MFC experiments were carried out using 100 to $12,000 \mathrm{ppm}$ concentrations of the essential oil.

GC-MS analysis The essential oil from aerial parts of $E$. triplinerve was analyzed by GC-MS electron impact ionization (EI) method on GC-17A gas chromatograph (Shimadzu) coupled to a GC-MS QP 5050A Mass Spectrometer (Shimadzu); fused silica capillary column (30m x $0.25 \mathrm{~mm} ; 0.25 \mathrm{~mm}$ film thickness), coated with DB-5 (J\&W); column temperature $100 \mathrm{oC}$ (2 $\mathrm{min}$ ) to $250 \mathrm{oC}$ at the rate of $3 \mathrm{oC} / \mathrm{min}$; carrier gas, helium at constant pressure of $90 \mathrm{Kpa}$. Acquisition parameters full scan; scan range 40-350 amu.

Identification of the constituents Constituent's identification was done by comparing the NIST library data of the peaks with those reported in literature. Percentage composition was computed from $\mathrm{GC}$ peak areas on DB-5 column without applying correction factors.

\section{RESULTS AND DISCUSSION}

Essential oil from the aerial parts of E. triplinerve was analyzed by GC-MS. The oil yield was $1.10 \%$. Thirty compounds (Table 1 ) were identified by GC-MS analysis with 2-tert-butyl1,4-methoxbenzene (74.27\%) and b-selinene (8.59\%) as major. Other notable compounds are b-pinene $(1.51 \%)$, b-pinene $(2.19 \%)$, a-phellandrene $(2.2 \%)$, thymolmethyl ether $(2.03 \%)$, b-selinene (1.28\%) and 6-isopropenyl-4, 8adimethyl-1, 2, 3, 5, 6, 7, 8, 8a-octahydronaphthalene2-ol (2.63\%). Gupta et al. (2004) reported selina-4(15), 7(11)-dien-8-one (36.6\%), b-caryophyllene $(14.7 \%)$ and d-elemene $(5.9 \%)$ as major constituents in the leaf oil of Indian E. triplinerve which are totally different from our sample. Results showed that the aerial parts oils of E. triplinerve was a complex mixture of numerous compounds; many of which were present in trace amounts. This confirms that the variations in the oil from local origin is not due to geographic divergence and ecological conditions, it may be due to different chemotype. 
The results of the in vitro antibacterial activity of the essential oil $(2,5,10,15$ and $20 \mu 1 /$ disc) against the ten bacterial strains (including Gram-positive and Gram-negative) are summarized in (Table 2.).It was observed that the essential oil was moderately effective against the test bacterial stains even at the lowest concentration $(2 \mu \mathrm{l} / \mathrm{disc})$ of the essential oil tested $10-25 \mathrm{~mm}$ diameter of zone of inhibition was recorded in $20 \mu \mathrm{l} /$ disc concentration. The highest zone inhibition was recorded against Salamella typhi $(21 \mathrm{~mm})$ followed by Shigella sonnei $(18 \mathrm{~mm})$ at a concentration of $20 \mu \mathrm{l} /$ disc (Table) on the other standard Ampicillin $20 \mathrm{mg} / \mathrm{disc}$ showed an average of $14-34 \mathrm{~mm}$ diameter of zone inhibition against the test organism.

The MIC value of the essential oil varied between 17000-21000ppm against the test bacteria (Table 3). The oil showed the lowest MIC (17000ppm) against Shigella typhae followed by $18000 \mathrm{ppm}$ against Shidella sonnei, Shigella dysenterae and Pseudomonas and highest (21000ppm) against Staphylococcus aureus, Bacillus cereus, Bacillus subtilis, Bacillus megaterium, Vibro cholera and E.coli. The oil exhibited the lowest MBC value (22000ppm) against Shigella sonnei, Shigella dysenterae, Pseudomonas and Salmonella typhae. The in vitro antifungal activity of essential oil against six phytopathogenic fungi was recorded and presented in (Table 4). The oil exhibited strong pathogen tested. In most of the cases, the essential oil exhibited better antifungal activity than the standard antibiotic, Nystain (Table 4). The MIC value of the essential oil was found of very between 6000-9000ppm against the test fungi (Table). The lowest MIC value (6000ppm) was recorded against $M$.phaseoline and $C$. corchori. MFC value of the essential oil were found to very between 8000- 12000ppm (Table 5). The oil exhibited the lowest MFC value (8000ppm) against $M$ phaseoline and $B$. thebromae. Similar antibacterial and antifungal activity of essential oil of other plant have also been reported. Medicinal as well as aromatic plant is an important source of potentially useful new compound for the discovery and development of chemotherapeutic against. E.triplinerve is a medicinal plant and also an important source of essential oil which contains 2- tert butyl-1, 4 methoxybenzene as major constituent $(74.3 \%)$ followed by b- selinene $(8.6 \%)$ is more antifungal compared to antibacterial agent. Further pharmacological and toxicological studies will be required to establish the therapeutic uses of this oil.

Table: 1 Chemical constituent of the essential oil from Eupatorium triplinerve aerial parts

\begin{tabular}{|c|l|l|}
\hline $\begin{array}{c}\text { PEAK } \\
\text { NO: }\end{array}$ & \multicolumn{1}{|c|}{ NAME OF THE CHEMICAL CONSITUENTS } & $\begin{array}{l}\text { PERCENTAGE } \\
\%\end{array}$ \\
\hline 1 & a- Thujene & 0.03 \\
\hline 2 & a- Pinene & 1.53 \\
\hline 3 & Sabinene & 0.03 \\
\hline 4 & b- Pinene & 2.19 \\
\hline 5 & c- Myrcene & 0.11 \\
\hline 6 & a- phellandrane & 2.20 \\
\hline 7 & O- cymene & 0.58 \\
\hline 8 & D- Limonene & 0.67 \\
\hline 9 & Terpinolene & 0.06 \\
\hline 10 & Sabinenehydrate & 0.07 \\
\hline 11 & Mthyl chavicol & 0.35 \\
\hline 12 & Thymol methyl ether & 2.03 \\
\hline 13 & Terpinyl acetate & 0.06 \\
\hline 14 & Anethole & 0.06 \\
\hline 15 & (+) Myrtenyl acetate & 0.04 \\
\hline
\end{tabular}




\begin{tabular}{|c|l|c|}
\hline 16 & Isolongifolene, 9,10- dehydro & 0.05 \\
\hline 17 & Camphene & 0.05 \\
\hline 18 & $\begin{array}{l}\text { 3- 0xabicyclo (4,2,0) oct - ene, ento- 8- methyl- } \\
\text { (2-propenyl) }\end{array}$ & 0.25 \\
\hline 19 & Cis - myrtanal acetate & 0.07 \\
\hline 20 & b- elemene & 0.57 \\
\hline 21 & a- gurjunene & 0.91 \\
\hline 22 & 2- tert- butyl- b- 1,4- metho oxy benzene & 74.27 \\
\hline 23 & a- caryophyiiene & 0.40 \\
\hline 24 & \begin{tabular}{c} 
3-4, dimethoxy - b- nitrostyrene \\
\hline 25
\end{tabular} & 0.17 \\
\hline 26 & a- Selinene & 1.28 \\
\hline 27 & b- Selinene & 8.59 \\
\hline 28 & Catchoulene & 0.11 \\
\hline 29 & $\begin{array}{l}\text { 6- isophopency 1-4, 8a dimethyl 1-2,3,5,6,7,8,8a, octa hydro } \\
\text { naphthalene- 2-01 }\end{array}$ & 0.35 \\
\hline 30 & Ayapanin & 2.63 \\
\hline & \multicolumn{1}{|c|}{} & 0.16 \\
\hline
\end{tabular}

Table : 2 Antibacterial activity essential oil from Eupatorium triplinerve aerial parts

\begin{tabular}{|l|l|c|c|c|c|c|c|}
\hline $\begin{array}{l}\text { S. } \\
\text { No }\end{array}$ & \multicolumn{1}{|c|}{ Bacterium } & $2 \mathrm{ml}$ & $5 \mathrm{ml}$ & $10 \mathrm{ml}$ & $15 \mathrm{ml}$ & $20 \mathrm{ml}$ & $\begin{array}{c}\text { Ampicillin } \\
20 \mathrm{mg} / \mathrm{disc}\end{array}$ \\
\hline & $\begin{array}{l}\text { Gram-Positive } \\
\text { Organism }\end{array}$ & & & & & & \\
\hline 1 & Staphylococcus aureus & 11 & 12 & 13 & 16 & 16 & 20 \\
\hline 2 & Bacillus megaterium & 10 & 11 & 11 & 12 & 13 & 21 \\
\hline 3 & Bacillus cereus & 11 & 12 & 14 & 15 & 17 & 21 \\
\hline 4 & Bacillus subtilis & 9 & 11 & 13 & 15 & 16 & 25 \\
\hline & $\begin{array}{l}\text { Gram-negative } \\
\text { organism }\end{array}$ & & & & & & \\
\hline 1 & Shigella dysenteriae & 12 & 13 & 14 & 15 & 17 & 34 \\
\hline 2 & Shigella sonnei & 12 & 14 & 15 & 16 & 18 & 30 \\
\hline 3 & Vibro chlerae & 10 & 11 & 12 & 13 & 14 & 25 \\
\hline 4 & Escherichia coli & 8 & 8 & 9 & 9 & 10 & 14 \\
\hline 5 & Salamella typhi & 13 & 15 & 16 & 18 & 21 & 29 \\
\hline 6 & Pseudomonas species & 11 & 12 & 13 & 14 & 15 & 19 \\
\hline
\end{tabular}


Table : 3 MIC and MBC of the essential oil from aerial parts from Eupatorium triplinerve against ten bacterial strains

\begin{tabular}{|c|c|c|c|}
\hline S.No & Bacteria & MIC(ppm) & MBC(ppm) \\
\hline 1 & Vibria cholerae & 21000 & 24000 \\
\hline 2 & E.coli & 21000 & 24000 \\
\hline 3 & Pseudomonas & 18000 & 22000 \\
\hline 4 & Salmonella typhae & 17000 & 22000 \\
\hline 5 & Shigella dysenterae & 18000 & 22000 \\
\hline 6 & Shigella sommei & 18000 & 22000 \\
\hline 7 & Staphylococcus aureus & 21000 & 23000 \\
\hline 8 & Bacillus cereus & 21000 & 23000 \\
\hline 9 & Bacillus subtilis & 21000 & 23000 \\
\hline 10 & Bacillus megaterium & 21000 & 23000 \\
\hline
\end{tabular}

MIC - Minimum inhibitory concentration $\quad \mathrm{MBC}-$ Minimum bacterial concentration

Table: 4 MIC and MFC essential oil from aerial parts of Eupatorium triplinerve against six fungal pathogens

\begin{tabular}{|c|c|c|c|}
\hline S.No & Fungus & MIC $(\mathrm{ppm})$ & MFC(ppm) \\
\hline 1 & Macrophomina phaseoline & 6000 & 8000 \\
\hline 2 & Colletrotrichum corchori & 6000 & 9000 \\
\hline 3 & Botryodiplodia & 7000 & 8000 \\
\hline 4 & Curuularia & 8000 & 10000 \\
\hline 5 & Fusarium equiseti & 8000 & 10000 \\
\hline 6 & Alternaria alternate & 9000 & 12000 \\
\hline
\end{tabular}

MIC - Minimum inhibitory concentration $\quad$ MFC - Minimum fungicidal concentration 
Table: 5 Antifungal activity of essential oil from Eupatorium triplinerve aerial

\begin{tabular}{|c|c|c|c|c|c|c|c|}
\hline S.No & Fungus & $100(\mathrm{ppm})$ & $250(\mathrm{ppm})$ & $500(\mathrm{ppm})$ & $750(\mathrm{ppm})$ & $\begin{array}{l}\text { Nystetin } \\
\text { (ppm) } \\
1000(\mathrm{ppm})\end{array}$ & $100(\mathrm{ppm})$ \\
\hline 1 & Fusarium equiseti & 60 & 67 & 72 & 75 & 85 & 52 \\
\hline 2 & Curuularia lunate & 59 & 64 & 70 & 73 & 82 & 68 \\
\hline 3 & $\begin{array}{l}\text { Macrophomina } \\
\text { phaseolina }\end{array}$ & 80 & 84 & 85 & 87 & 89 & 70 \\
\hline 4 & Alternaria alternate & 70 & 73 & 76 & 77 & 82 & 53 \\
\hline 5 & $\begin{array}{l}\text { Colletotrichum } \\
\text { corchori }\end{array}$ & 71 & 72 & 75 & 78 & 81 & 40 \\
\hline 6 & $\begin{array}{l}\text { Botryodiplodia } \\
\text { theobromae }\end{array}$ & 79 & 81 & 84 & 85 & 88 & 69 \\
\hline
\end{tabular}

\section{REFERENCES}

[1] Ahmed, A.M.A., M.S. Rahman and M.N. Anwar. 2002. Antimicrobial activity of extracts and crude alkaloids isolated from the leaf of Adhatoda vasica Nees. Bangladesh J. Life Sci. 15(2) 125-128.

[2] Canales-Martinez, M., Hernandez-Delgado, T., Flores Ortiz, C., Duran Diaz, A. 2005. Antimicrobial Activity of Alternant era caracasana. Pharmaceutical Biology, 43(4): 305-307

[3] Ghani, A. 1998. Medicinal plants of Bangladesh: Chemical constituents and uses. 1st edn. Asiatic Society of Bangladesh. pp. 174.

[4] Garg, S.C. and Nakhare, S. 1993. Studies on the essential oil from the flower of Eupatorium triplinerve. Ind. Perfum. 37: 318-323.

[5] Garg, S.C. and Nigam, S.S. 1970. Chemical examination of the essential oil from the leaves of Eupatorium triplinerve. Flav. Ind. 1: 469-472.

[6] Ghani, A. 2003. Medicinal Plants of Bangladesh with Chemical constituents and Uses. $2^{\text {nd }}$ edn. AsiatiSociety of Bangladesh, pp 224-225.

[7] Gupta, D., Charle, R. and Garg, S. N. 2004.Chemical composition of the essential oil from the leaves of Eupatorium triplinerve Vahl. J. Essentl. Oil Res. 16(5): 473-475 
[8] Jones, N.R., Barry, L.A., Gavan, L.T. and Washington II, J.A. 1985. Susceptibility tests: Microdilution and macrodilution broth procedures.In manual of clinical microbiology (Lennette EH, bellows A, Hausler Jr. W.J and Shadomy HJ eds.) $4^{\text {th }}$ edn. American society of microbiology, Washington DC, pp 972-976.

[9] Kokate, C., and Verma, K.C. 1971. Pharmacological studies on the essential oil of Eupatorium triplinerve. Flavour Ind.2 (3):177-180.

[10] Sharma, S.K. and Singh, V.P. 1979. The antifungal activity of some essential oils. Indian Drugs Pharm Ind. 14 (1): 3-6.

[11] Yadava, R.N. and Saini, V.K. 1980. In vitro Anti microbial efficacy of the essential oil of Eupatorium triplinerve leaves. Ind. Perfum.34 (1): 61-63. 